\title{
CHEMICAL COMPOSITION OF EDIBLE POTATO TUBERS IN RETAIL OUTLETS IN EAST-CENTRAL POLAND
}

\author{
Krystyna Zarzecka', Marek Gugała', Iwona Mystkowska', Magdalena Zarzecka² \\ 1 Chair of Plant Cultivation, University of Natural Sciences and Humanities in Siedlce, B. Prusa 14, 08-110 \\ Siedlce, Poland, e-mail: kzarzecka@uph.edu.pl; gugala@uph.edu.pl \\ 2 Medical University of Białystok, J. Kilinskiego 1, 15-089 Białystok, Poland
}

Received: 2014.06.18

Accepted: 2014.10.17

Published: 2015.01.02

\begin{abstract}
The work was an attempt to determine and describe certain quality characteristics of edible potato on sale in Siedlce and Międzyrzec Podlaski. Potato tubers for examination were purchased in 3 kinds of retail outlets (ten shops of each kind) in east-central Poland. A total of 90 samples were collected to determine tuber size, protein and vitamin $\mathrm{C}$ content, reducing sugars and sucrose content. Potatoes purchased in all kinds of outlets met the standards set for tuber size. Potatoes bought in supermarkets had a better chemical composition than tubers purchased in groceries or fruit and vegetable shops. All the potato tubers were a good staple.
\end{abstract}

Keywords: potato, vitamin C, reducing sugars, sucrose, total protein.

\section{INTRODUCTION}

Potato is the major crop plant which, alongside wheat, maize and rice, is the staple food worldwide [Zgórska 2013]. Although the area of potato grown has been declining, Poland remains a significant potato producer in Europe. The country is a leader of potato production in the European Union surpassed by Germany only [Rynek ziemniaka 2013].

Appropriate nutrition, that is supplying sufficient levels of energy, nutrients and minerals, is a precondition determining the right functioning of the organism. Potato is one of major food crops and recently there has been an increasing interest in potato-based diets due to the crop's nutritional and dietetic aspects as well as medicinal use [Jansky 2010; Jansen et al. 2001; Stypa, Zgórska 2010].

Potato is a central and distinctive element of everyday diet in Poland due to its high nutritional and culinary value. Moreover, it is available all year round and consumed in large quantities. Per capita potato consumption in recent years has ranged from 107 to $130 \mathrm{~kg}$, being $107 \mathrm{~kg}$ per year in the 2012/2013 season [Rynek ziemniaka 2013].
It should also be emphasised that a wide range of cultivars has been available with as many as 129 cultivars being registered with the National List in 2011, including 101 edible varieties [Lista opisowa odmian 2013].

Potato nutritional value is determined by tuber content of chemical components which are important for human nutrition (starch, protein, vitamins, total sugars, reducing sugars and minerals) as well as low concentration or lack of toxic compounds (glycoalkaloids, nitrates, heavy metals, pesticides) [Kolasa 1993; Lisińska 2006; Love, Pavek 2008]. Protein is one of major potato tuber components which, although not abundant, is a key element determining tubers' nutritional value due to the so-called 'pure protein' (making up $35-65 \%$ nitrates), which contains all the exogenous amino acids [Leszczyński 2012; TajnerCzopek 2006]. The biological value of potato is higher than that of the majority of plant proteins, for example pea, wheat and rice proteins [Bártová et al. 2009; Öztürk et al. 2010; Pęksa 2003]. Ascorbic acid and dehydroascorbic acid, which are vitamin $\mathrm{C}$ constituents, are other potato tuber components. Vitamin C content is very much different and is mainly affected by potato cultivar 
and environmental conditions [Leszczyński 2012; Love, Pavek 2008; Tajner-Czopek 2006]. What is more, vitamin $\mathrm{C}$ is the strongest water-soluble antioxidant protecting the organism against cancer, particularly stomach and oesophagus cancer [Czerwiecki 2009; Grajek 2004; Kris-Etherton et al. 2002]. Sugars are yet another potato components affecting tuber suitability for cooking and processing. They include total sugars, reducing sugars and sucrose. Increased concentrations of these compounds result in edible tubers having a palpable, sweeter taste and their flesh blackening more rapidly, which is a very undesirable process particularly in tubers destined for chips and crisps [Sawicka, Pszczółkowski 2005; Tajner-Czopek 2006; Zgórska, Grudzińska 2012].

As healthy and "convenient" food and consumption of unprocessed potato are increasingly popular with consumers, more and more studies of edible tuber quality are conducted. Furthermore, a change in the way and place of purchasing edible tubers has been recently observed, whether for immediate consumption or for storage throughout autumn and winter months. Instead of purchases made on markets or directly from farmers, potatoes are more and more frequently bought in groceries, fruit and vegetable shops or supermarkets [Chotkowski, Rembeza 2005]. This, coupled with the fact that more and more supermarkets offer a wide range of cultivars, necessitates the studies to examine whether appealing appearance of the product is accompanied with internal quality traits meeting the specifications set for edible potato.

\section{MATERIALS AND METHODS}

Samples of edible potato tubers were purchased in three kinds of outlets, all of them operating either in Siedlce or Międzyrzec Podlaski, east-central Poland: supermarkets, grocery shops and fruit and vegetable shops. Three packets of potato tubers (three replicates during laboratory analyses), each weighing $2.0-2.5 \mathrm{~kg}$, were purchased in 10 shops representing each kind of outlet (Table 1). A total of 90 samples were analysed. Tuber size and share (by weight) in the overall sample weight was determined following the Regulation of the Minister of Agriculture and Rural Development (MAiRD) [Rozporządzenie 2003]. Percentage of tubers with diameter above $50 \mathrm{~mm}$ was determined, too. Chemical analyses were conducted on dry (total nitrogen) and fresh material (vitamin C, sugars) in three replicates. Total protein content was calculated based on total nitrogen content using the conversion value of 6.25. Total nitrogen was determined using the Kjeldahl method on a 2300 Kjeltec Analizer Unit, and vitamin $\mathrm{C}$ content was analysed following the Pijanowski method. Reducing sugars (glucose + fructose) and total sugars (glucose + fructose + sucrose) were determined by means of the Luff-Schoorl method, sucrose content being calculated as total sugars after hydrolysis minus reducing sugars $\times 0.95$ [Ostrowska et al. 1991]. The results were statistically analysed by one-way variance analysis at the significance level of 0.05 .

\section{RESULTS AND DISCUSSION}

The size of all the tubers collected from supermarkets, groceries and fruit and vegetable shops met the specifications set in the Regulation of MAiRD [Rozporządzenie 2003]. Their diameter was over $35 \mathrm{~mm}$ (Table 2). The percentage of tubers with the diameter of over $50 \mathrm{~mm}$ was the highest in samples taken in supermarkets $(75.6 \%$ on average), which probably resulted from the applied technologies in potato cultivation and the presence of foreign cultivars.

According to Lisińska [2006], protein content in fresh matter ranged from 1.7 to $2.3 \%$ whereas Jansen et al. [2001], who examined 466 cultivars, reported the range of 4.5 to $13.6 \%$ d.m., the average concentration amounting to $8.12 \%$. In the present study, protein content fell within the range of $11.57-14.08 \%$ d.m. The highest av-

Table 1. Methodological data

\begin{tabular}{|l|l|l|}
\hline \multicolumn{1}{|c|}{ Kind of outlet } & \multicolumn{1}{|c|}{ Place of purchase } & \multicolumn{1}{|c|}{ Potato cultivars } \\
\hline Supermarket & $\begin{array}{l}\text { Biedronka (3 shops), Stokrotka (2), Carefour (1), } \\
\text { Tesco (1), Topaz (2), Lidl (1) }\end{array}$ & $\begin{array}{l}\text { Melody (1), Augusta (1), Milva (1), } \\
\text { Satina (2), Asterix (1), Sante (2)* }\end{array}$ \\
\hline Grocery shop & $\begin{array}{l}\text { Delikatesy (4 shops), PSS Społem (3), Carlos (2), } \\
\text { Mini Market (1) }\end{array}$ & Irga (8), Lord (1), Tajfun (1) \\
\hline Fruit and vegetable shop & Small local shops (10) & Irga (6), Lord (2), Vineta (2) \\
\hline
\end{tabular}

* Two cultivars were not labelled. 
Table 2. Size of potato tubers and their total protein and vitamin C contents

\begin{tabular}{|l|c|c|c|c|c|c|}
\hline \multirow{2}{*}{ Kind of outlet } & \multicolumn{2}{c|}{$\begin{array}{c}\text { Percentage share of tubers, } \\
\text { diameter }\end{array}$} & \multicolumn{2}{c|}{$\begin{array}{c}\text { Total protein content } \\
\text { (\% dry matter) }\end{array}$} & \multicolumn{2}{c|}{$\begin{array}{c}\text { Vitamin C content } \\
\left(\mathrm{mg}^{*} \mathrm{~kg}^{-1} \text { fresh matter }\right)\end{array}$} \\
\cline { 2 - 7 } & $>35 \mathrm{~mm}$ & $>50 \mathrm{~mm}$ & mean & $\begin{array}{c}\text { range } \\
\text { min-max }\end{array}$ & mean & $\begin{array}{c}\text { range } \\
\text { min-max }\end{array}$ \\
\hline Supermarket & 100.0 & 75.6 & $13.82 \mathrm{a}$ & $13.28-14.07$ & $214.4 \mathrm{a}$ & $201-221$ \\
\hline Grocery shop & 100.0 & 37.7 & $13.76 \mathrm{a}$ & $13.44-14.08$ & $205.4 \mathrm{~b}$ & $198-209$ \\
\hline Fruit and vegetable shop & 100.0 & 51.6 & $12.07 \mathrm{~b}$ & $11.57-12.59$ & $206.2 \mathrm{~b}$ & $200-211$ \\
\hline
\end{tabular}

$\mathrm{a}, \mathrm{b}-$ mean values denoted by the same letter do not differ significantly at $\mathrm{p}=0.05$.

erage concentration was determined in tubers purchased in supermarkets and significantly the lowest in potatoes collected from fruit and vegetable shops, 13.82 and $12.07 \%$, respectively (Table 2). Similar values were reported by Zarzecka and Gugała [2006] but their results were affected by agronomical practices and weather conditions during the study years. In turn, Czech and Turkish authors [Bártová et al. 2009; Öztürk et al. 2010] reported lower protein contents ranging from 6.84 to $10.20 \%$.

Vitamin $\mathrm{C}$ content of potato tubers averaged $100-250 \mathrm{mg} / \mathrm{kg}$ of fresh matter [Kita, Lisińska 2007] and was the highest in samples of potato purchased in supermarkets, $214.4 \mathrm{mg} / \mathrm{kg}$, on average. The average vitamin $\mathrm{C}$ contents were significantly lower for the two remaining kinds of shops. Other authors [Love, Pavek 2008] reported similar values. There are many reports mentioning vitamin $\mathrm{C}$ loses ranging from 20 to $80 \%$ during heat treatment of tubers, the highest following boiling or frying in oil [Kita, Lisińska 2007; Navarre et al. 2010]. Daily consumption of 250-300 g potatoes provides the human body with 40 to $70 \%$ vitamin $\mathrm{C}$ so consumers should pay close attention to the cultivar and cooking method they choose [Pęksa 2003].

Regulations set the following standards pertaining to the quality characteristics of potato for direct cooking or for chips and crisps: tubers should contain, respectively, less than $0.5,0.25$ to less than 0.5 and less than $25 \%$ of tuber fresh matter [Zgórska, Frydecka-Mazurczyk 2002]. Grudzińska and Zgórska [2008] reported low re- ducing sugars (less than $25 \%$ ) in tubers immediately after harvest and after a period of storage. In the present work, tubers for direct consumption purchased in all kinds of outlets met the specifications set for reducing sugars (Table 3). Least reducing sugars were accumulated by potatoes sold in supermarkets $(0.370 \%$, on average). They were significantly higher in groceries as well as fruit and vegetable shops. Also, sucrose content of tubers was low in the three kinds of outlets but the between-mean differences were not statistically significant. Sawicka and Pszczółkowski [2005] reported similar, though slightly lower, reducing sugars and sucrose content, which was probably due to the fact that the determinations were made just after harvest. During storage starch breaks down into sucrose and then to reducing sugars (glucose + fructose), after-cooking darkening appears and tubers taste sweeter [Leszczyński 2012]. Based on correlation coefficients, Grudzińska and Zgórska 2008] concluded that starch content and reducing sugars were significantly and negatively correlated, which means that an increase in reducing sugars was followed by reduction in starch content.

\section{CONCLUSIONS}

1. Potatoes purchased in all three types of outlets in Siedlce and Międzyrzec Podlaski met standards set for edible potato tuber size. Samples taken in supermarkets had the highest percentage of large tubers.

Table 3. Reducing sugars and sucrose content in potato tubers

\begin{tabular}{|l|c|c|c|c|}
\hline \multirow{2}{*}{\multicolumn{1}{|c|}{ Kind of outlet }} & \multicolumn{2}{c|}{ Reducing sugars (\%) } & \multicolumn{2}{c|}{ Sucrose (\%) } \\
\cline { 2 - 5 } & mean & $\begin{array}{c}\text { range } \\
\text { min-max }\end{array}$ & mean & $\begin{array}{c}\text { range } \\
\text { min-max }\end{array}$ \\
\hline Supermarket & $0.370 \mathrm{a}$ & $0.361-0.379$ & $0.245 \mathrm{a}$ & $0.238-0.256$ \\
\hline Grocery shop & $0.376 \mathrm{~b}$ & $0.345-0.391$ & $0.245 \mathrm{a}$ & $0.208-0.276$ \\
\hline Fruit and vegetable shop & $0.375 \mathrm{~b}$ & $0.360-0.390$ & $0.242 \mathrm{a}$ & $0.209-0.266$ \\
\hline
\end{tabular}

$\mathrm{a}, \mathrm{b}-$ mean values denoted by the same letter do not differ significantly at $\mathrm{p}=0.05$. 
2. Total protein content, vitamin C content and reducing sugars in the tubers were affected by the place of purchase. Again, tubers bought in supermarkets had the best chemical composition.

3. The chemical composition of edible potatoes was good, regardless of the kind of outlet they were collected from.

\section{REFERENCES}

1. Bártová V., Bárta J., Diviš J., Švajner J., Peterka J. 2009. Crude protein content in tubers of starch processing potato cultivars in dependence on different agro-ecological conditions. Journal Central European Agriculture, 10(1), 57-66.

2. Chotkowski J., Rembeza J. 2005. Preferencje konsumentów i zmiany w spożyciu ziemniaków. Roczniki Naukowe Stowarzyszenia Ekonomistów Rolnictwa i Agrobiznesu, VII, 8, 42-49.

3. Czerwiecki L. 2009. Współczesne poglądy na rolę przeciwutleniaczy roślinnych w profilaktyce chorób cywilizacyjnych. Roczniki Państwowego Zakładu Higieny, 60(3), 201-206.

4. Grajek W. 2004. Rola przeciwutleniaczy w zmniejszaniu ryzyka wystąpienia nowotworów i chorób układu krążenia. Żywność Nauka Technologia Jakość, 1(38), 3-11.

5. Grudzińska M., Zgórska K. 2008. Wpływ zawartości cukrów w bulwach ziemniaka na barwę chipsów. Żywność Nauka Technologia Jakość, 5(60), 107-115.

6. Grudzińska M., Zgórska K. 2010. Wpływ efektywności zabiegu rekondycjonowania wybranych odmian bulw ziemniaka na barwę frytek. Nauka Przyroda Technologie, 4(2), 1-8.

7. Jansky S.H. 2010. Potato flavor. American Journal of Potato Research, 87, 209-217.

8. Jansen G., Flamme W., Shüler K., Vandrey M. 2001. Tuber and starch quality of wild and cultivated potato species and cultivars. Potato Research, $44,137-146$.

9. Jemison J.M. Jr., Sexton P., Ellen M., Camire M.E. 2008. Factors influencing consumer preference of fresh potato varieties in Maine. American Journal of. Potato Research, 85, 140-149.

10. Kita A., Lisińska G. 2007. Ocena składu chemicznego i jakości organoleptycznej mrożonych produktów ziemniaczanych pochodzących z sieci handlowej. Żywność Nauka Technologia Jakość, 3(52), 15-27.

11. Kolasa K.M. 1993. The potato and human nutrition. American Potato Journal, 70, 375-384.

12. Kris-Etherton P.M., Hecker K.D., Bonanome A., Coval S.M., Binkoski A.E., Hilpert K.F., Griel A.E.
2002. Bioactive compounds in foods: their role in the prevention of cardiovascular disease and cancer. American Journal Medicine, 113, 71-88.

13. Leszczyński W. 2012. Żywieniowa wartość ziemniaka i przetworów ziemniaczanych (Przegląd literatury). Biul. IHAR, 266, 5-20.

14. Lisińska G. 2006. Wartość technologiczna i jakość konsumpcyjna polskich odmian ziemniaka. Zeszyty Problemowe Postępów Nauk Rolniczych, 511, 81-94.

15. Lista opisowa odmian. Rośliny rolnicze. 2013. Cz. 2. Wyd. COBORU, Słupia Wielka, 1-202.

16. Love S.L., Pavek J.J. 2008. Positioning the potato as a primary food source of vitamin C. American Journal of Potato Research, 85 (4), 277-285.

17. Navarre D.A., Shakya R., Holden J., Kumar S. 2010. The effect of different cooking methods on phenolics and vitamin $\mathrm{C}$ in developmentally young potato tubers. American Journalof Potato Research, $87,350-359$.

18. Ostrowska A., Gawliński S., Szczubiałkowa Z. 1991. Metody analizy i oceny właściwości gleb i roślin. Wyd. Inst. Ochr. Środ. Warszawa.

19. Öztürk E., Kavurmaci Z., Kara K., Polat T. 2010. The effects of different nitrogen and phosphorus rates on some quality traits of potato. Potato Research., 53, 309-312.

20. Pęksa A. 2003. Białko ziemniaczane - charakterystyka i właściwości. Postępy Nauk Rolniczych, 5, 79-94.

21. Rozporządzenie Ministra Rolnictwa i Rozwoju Wsi w sprawie szczegółowych wymagań w zakresie jakości handlowej ziemniaków. Dz. U. nr 194 poz. $1900 \mathrm{z} 2003$ roku.

22. Rynek ziemniaka. Stan i perspektywy. Analizy rynkowe. 2013. Wyd. IERiGŻ-PIB, ARR, MRiRW, 40, 1-24.

23. Sawicka B., Pszczółkowski P. 2005. Dry matter and carbohydrates content in the tubers of very early potato varieties cultivated under coverage. Acta Scientarium Polonorum Hortorum Cultus, 4(2), 111-122.

24. Stypa I., Zgórska K. 2010. Ziemniak nasz powszedni. Wyd. IHAR-PIB, Bonin, 1-24.

25. Tajner-Czopek A. 2006. Metodyka określania wartości technologicznej i jakości konsumpcyjnej ziemniaka. Zeszyty Problemowe Postępów Nauk Rolniczych, 511, 95-103.

26. Zarzecka K. 2009. Potato as a global plant nutritional, dietary and medicinal values. Rozprawy Naukowe PWSZ im. Jana Pawła II w Białej Podlaskiej, T. III, 163-175.

27.Zarzecka K., Gugała M. 2006. Zawartość białka ogólnego i właściwego $\mathrm{w}$ bulwach ziemniaka $\mathrm{w}$ zależności od sposobów uprawy roli i odchwasz- 
czania. Acta Scientarium Polonorum Agricultura, 5(2), 107-115.

28. Zarzecka K., Gugała M., Mystkowska I. 2009. The effect of agricultural treatments on the content of total and protein nitrogen in potato tubers. Ecological Chemistry and Engineering, A 16(8), 1065-1070.

29. Zgórska K. 2013. Wykorzystanie ziemniaka do celów spożywczych i przemysłowych. Inżynieria
Przetwórstwa Spożywczego, 3/4, 7, 5-9.

30. Zgórska K., Frydecka-Mazurczyk A. 2002. Normy i wymagania jakościowe ziemniaków jadalnych i do przetwórstwa spożywczego. W: Produkcja i rynek ziemniaków jadalnych. Red. J. Chotkowski. Wyd. Wieś Jutra, Warszawa, 183-192.

31. Zgórska K., Grudzińska M. 2012. Zmiany wybranych cech jakości bulw ziemniaka w czasie przechowywania. Acta Agrophysica, 19(1), 203-214. 